\title{
An Optimal Governance Model of Land Use in Watershed: The Case of the Paldang Reservoir
}

\author{
Sung-Bae Kim* \\ Soongsil University
}

\begin{abstract}
This study introduces an optimal governance model of land use in watershed areas from a property rights perspective, focusing on the Paldang reservoir in Korea. The particular model is developed based on the premise that land use decisions, which differ in their attributes, can properly be aligned with governance mechanism in such a way that minimizes the governance costs. Given the intrinsic limitations of the measurement of governance costs, this study applies the discrete structural analysis for the alignment. This model developed in such a manner prescribes very diverse and specific governance structures, and as such, the relevance of this model to the real world situation is much greater. The diversification of policy measures also provides the residents in the watershed of Paldang reservoir with the opportunity to develop a series of environmentally sensitive and economically viable patterns for growth and diversity.
\end{abstract}

* Associate Professor, Department of Public Administration, Soongsil University, 1-1 Sangdo-Dong, Dongjak-Ku, Seoul, Korea Email address: graal@ssu.ac.kr 
An Optimal Governance Model of Land Use in Watershed:

The Case of the Paldang Reservoir

\section{INTRODUCTION}

Governance of land use in the watershed of drinking water reservoir is intriguing for several reasons. To begin with, it is the characteristics of the watershed that costs and benefits are separated between those upstream and downstream. Secondly, while it is a paramount consideration of government to protect the waters in the watershed, the protection must be accomplished without jeopardizing the livelihood or the quality of life of people living within the watershed boundaries. Thirdly, it is extremely complicate matter to understand the precise mechanism on which the land use activities impact on the quality of water. Finally, there are possibilities that land use activities may bring about potentially very serious problems caused by the contamination of drinking water.

For these reason, many government in charge of controlling the land use of watershed confronts serious difficulties in designing proper policy measures. Typical response by these governments is to adopt policy measures based on zoning which may either result in wholesale changes in land use or prohibit the land use activities deemed to produce pollution. Under this approach, it is quite likely that a vicious circle can arise. The degradation of water quality leads to more strict regulation of land use in watershed areas and to the resultant dissatisfaction of watershed residents; the dissatisfaction of resident lower regulatory compliance leading to 
stronger regulations with strengthened residents' opposition.

This paper develops an optimal governance model of land use in watershed from a property rights perspective with special reference to Paldang reservoir in Korea. We believe that this model can contribute not only to the discontinuation of this vicious circle, but also to the improvement of the reservoir's water quality. It is because the property rights perspective allows to develop policy measures which focus, for the most part, on modifying specific activities within particular land use categories. Thus, we can differentiate the land use activities being controlled with strict regulations from others with incentive based approaches. The diversification of policy measures may provide the residents of watershed the opportunity to develop a series of environmentally sensitive and economically viable patterns for growth and diversity.

In this study, Paldang reservoir is selected as the case study area. The reservoir is one of Korea's major reservoirs, and one from which most people in Seoul and the surrounding areas receive their drinking water. Some 20 million people, or nearly half of the Korean population, secure water from this reservoir. Recently, however, signs have emerged that the quality of the Paldang reservoir's water has been steadily decreasing. It is believed that the underlying cause of this degradation is the vicious circle described previously. Thus, the Paldang reservoir is in needy of an optimal land use governance model that achieves the dual objectives.

The remainder of this paper is organized as follows. Section II discusses conceptually the important features of land use governance from the property rights perspective. Section III describes the major characteristics of Paldang reservoir and it watershed. Section IV present an optimal 
governance model of land use in watershed of Paldang reservoir from the property rights perspective. Final section draws several conclusions.

\section{LAND USE GOVERNANCE FROM A PROPERTY RIGHTS PERSPECTIVE}

\section{Property Rights Perspective}

A property rights perspective is basically concerned with the analysis of the relationship between the structure of property rights and the incentive structure of economic agents in the allocation of resources. The central thesis of the property rights perspective is that the particular structure of property rights present in an economy influences the allocation and utilization of economic resources in specific and predictable ways (Furubotn and Pejovich 1991). Thus, the policy question most often addressed from this perspective is that of how to delineate the proper forms of property rights structures so as to assure the efficient allocation of resources.

The early notion of a property rights approach can be found in a seminal paper written by Coase (1960), now known as the Coase theorem.1 Since the publication of Coase's paper, scholars have attempted to extend the approach in several directions. Though the theorem has been spread to apply to many different situations, two general aspects may be identified.

1) In this theorem, Coase demonstrated that with regards to problems of external costs, the party to whom exclusive property rights are assigned does not necessarily affect the resulting output equilibrium. This theorem was developed on the assumptions that rights are fully assigned, exchanges may be conducted at no cost, the resulting contracts are easily enforceable, and that initial distribution does not affect demand. 
The first is that while the theory suggested by Coase was developed assuming that transaction costs were zero, ensuing studies applied the approach to situations in which transaction costs were prevalent.2 The other aspect is that many of these ensuing studies have made a contribution to the further analysis of the relationship between property rights and transaction costs.

Based on these studies, the contemporary property rights approach attempts to figure out the relationship between resource allocation and the structure of property rights in situations where transaction costs are not zero. The key proposition of this approach would be that, in cases where production costs and institutional knowledge are a given, individuals seeking optimal resource allocation will tend to choose an institutional structure that minimizes transaction costs (Furubotn \& Richter, 1991).

The following discussion is devoted to an elaboration of the governance models of land use from the property rights approach. To do so requires to redefine the concept of property rights, focusing on its operational facet. In keeping with Mercuro \& Medema's definition (1997), this paper defines property rights as the authority to make decision on how and in what sector specific resources may be put.

Having defined property rights, it needs to elaborate two closely related elements of land use governance. The first element is concerned with the allocation of the property rights, i.e. to whom the authority to make decisions for land use should be allocated. Drawing from the studies on the protection of property rights, we adopt a few rules on the assignment of property rights suggested by Posner (Posner, 1992). This rule postulates

2) Coase himself noted that his theorem should be used as a stepping stone to develop an analysis for an economy with positive transaction costs (Coase 1991). 
that property rights should be assigned to the party to whom the right would be most valuable. The second element is concerned with the resolution of the conflicts arising form the exercise of property rights. To this end, it needs to figure out the rules to coordinate the numerous decisions made by individual landowners. The theoretical foundation for such coordination rules can also be found in the same literatures.3 Among such rules, the most typical are property, liability, and inalienability rules (Calabresi \& Melamed, 1972). For the purpose of this study, property and liability rules, as defined in the above-mentioned literature, can be utilized without any modifications. Some modifications, however, must be made to the inalienability rules. As in the study conducted by Rose-Ackerman (1985), inalienability rules are classified according to the means of restricting property rights. These modified inalienability rules consist of the conventional inalienability rule, an inalienability rule with limited use, an inalienability rule with required use, and an inalienability rule with coerced use. In this study, these two elements have been combined and referred to as governance mechanism.

\section{Land Use Governance from Property Rights Perspective}

In the following section, the details of the governance model will be described. The major feature of the governance model can be characterized by various governance mechanisms that can be employed to control land use activities. These governance mechanisms are classified after having taken into consideration both the assignment of the decision making authority and

3) Some scholars have noted that the systematic analysis and resultant taxonomy of property rights protection rules have been one of the most important contributions of property rights studies since Coase (Krauss, 1999). 
the rules to control and coordinate land use decisions, as noted previously. A complete list of governance mechanisms is presented in Table 1.

The governance mechanisms classified as $\mathrm{P}-1$ and $\mathrm{P}-2$ are developed based on property rules. Under $\mathrm{P}-1$, individual A may not make any decisions on land use activities that may interfere with B without the latter's consent. For example, if I own a lakefront lot and have access to the water, under this governance mechanism, others may only use my land for access upon gaining my permission. Under $\mathrm{P}-2$, $\mathrm{A}$ is free to make these decisions which may interfere with B, and A can only be stopped if B buys off A. Consider, for example, a home separated from a lake by a piece of land upon which the owner decides to construct a fence, thereby blocking the homeowner's view of the lake (Bromley, 1991). Under this mechanism, the landowner possesses the property right to interfere and thus he can be prevented from doing so if the homeowner buys the lot. Under both of these rules, the government may play a limited role that comprises of the definition and redistribution of property rights.

The governance mechanisms, identified as $\mathrm{L}-1$ and $\mathrm{L}-2$, have been developed based on liability rules. Under L-1, A may proceed to make land use activity decisions even though those activities may interfere with B, however in such instances B must be compensated. For example, consider the lakefront lot example previously discussed. Under this structure, while others may use the land for access without the owner's permission, they must pay compensation for the interference. Under L-2, B may stop A from activities that may interfere with B's interest, but must compensate A for the cessation. Under this mechanism, the homeowner in the above example can retain his view of the lake, if he can afford to compensate the would-be fence builder. Under both these rules, the government is expected to play 
the role of a disinterested assessor responsible for determining the amount of compensation.

A governance mechanism based on conventional inalienability rules implies that no decision can be made under this structure (I-1). In fact, in such situations, there is not really any individual decision authority to speak of. Under the modified inalienability rules with required use (I-2), while nothing is forbidden, some uses are required. A historical preservation regulation would be a good example of such a situation as it typically requires that the owner preserve at least the facades of certain buildings, that permission be acquired prior to any alterations of the affected portions of the buildings, and that any demolition be permitted only under very restrictive conditions.

Under the inalienability rules with limited use (I-3), while nothing is required there are some things that are forbidden. For example, land use zoning laws may forbid the building of apartment blocks or any commercial development on some residential lots. Under the modified inalienability rules with coerced use (I-4), all permitted activities are required and all other uses are forbidden. Under this mechanism, requirements are imposed on land use decision makers, however such requirements can be set aside if they are willing to waive their decision-making rights as well. For example, in Korea ordinances for the development of new towns require that land be distributed to the concerned parties on the condition that the land be developed in a specified way and within a limited time period. As such, it is clear that under such governance mechanisms derived from inalienability rules the role of the government is stronger and more varied. 


\section{LAND USE IN WATERSHED OF PALDANG RESERVOIR}

\section{Paldang Reservoir and Watershed}

The Paldang reservoir is one of Korea's major reservoirs, and one from which most people in Seoul and the surrounding areas receive their drinking water. Some 20 million people, or nearly half of the Korean population, secure water from this reservoir. This reservoir is located in the middle of Kyunggi province and the eastern part of Seoul. It was constructed from 1966 to 1974 for the dual purposes of providing drinking water and generating hydro-electric power (Figure 1). The Paldang reservoir is a river type reservoir where three major rivers are converge and flow further down to western sea of Korea peninsula.

The watershed of Paldang reservoir covers $20,459 \mathrm{~km}$ comprising the portions of 3 provinces, 11cities and 18 counties. The watersheds are divided into four interrelated sub-regions, including the Northern Han river area, Southern Han river area, Kyungan river area and Paldang drinking water preservation area. The watershed is home to over 2 million people and the number of population is gradually increasing over the years (MOC, 2003). Of these, about 65\% are residing in the Southern Han river sub-region, 24\% are in the Northern Han river sub-region and 10\% are in Kyungan river sub-region. Except for the Kyungan sub-region, over $60 \%$ of the population is classified as urban residents. The proportion is much lower in Kyungan sub-region amounting to about 50\%.

Table 2 presents the land use patterns in the watershed of Paldang 
reservoir. As is the case in other watershed, forestland account for over $80 \%$ of entire watershed. The agricultural land use account for $12.4 \%$; and pastureland account for $2.6 \%$ and most of them are utilized for livestock production. If we differentiate this statistic by sub-region, we can find little different pattern. Particularly in Kyungan sub-region, unlike other sub-regions, the proportion accounted by forest are just 66\% with substantially higher proportion of agricultural land use, $21.4 \%$. Also, much higher is the proportion of urban land use amounting to $3.6 \%$ and pasture areas to $4.4 \%$.

As for the quality of water in the Paldang reservoir, the statistics provided by MOE presents the changing pattern (MOC, 2003). In 1990, the quality of water in Paldang reservoir recorded the first grade water. Recently, it is recognized that the quality of the Paldang reservoir's water has been steadily decreasing over the years. In terms of BOD standards, the water quality of the Paldang reservoir fell to the second grade (2 ppm) in 2002 from its previous first grade level. If this trend continues unabated, it is expected that the water quality will fall to the third grade (over $3 \mathrm{ppm}$ ) by 2006. If we examine water quality by sub-watershed system, most serious problem can be found in Kyungan river sub-region. Water quality of the Kyungan river appears to be much worse than other rivers and more importantly, it appears that the water quality is continuously degrading.

2. Water Quality Impacts of Land Use Activities

The section attempts to identify the impacts of land use activities on the 
quality of water in Paldang reservoir. Generally, land use activities can have important impacts on water quality, which in turn may have negative or, in some cases, positive effects on downstream uses of water. Impacts include the changes in sediment load and concentration of nutrients, salts, metals and agrochemicals, the influx of pathogens, and a change in the temperature regime.

Table 3 shows the amount of pollution contributed by each sources of pollution in Paldang reservoir. The statistics in the table indicate that except for phosphorus, both over 55\% of nutrient and nitrogen load can be accounted for by the point sources pollution. The non-point source pollution contributed about $44 \%$ of nutrient, $44.3 \%$ of nitrogen load and only $21 \%$ of phosphorus. Table also indicates that wastewater from residential and industrial areas, and livestock production are responsible for 29\%, 7.9\% and $17.9 \%$ of point source pollution respectively.

In the following, we will examine the water quality impacts of land use activities in the watershed of Paldang reservoir. To begin with, urban land uses contributes to degradation of water quality in several ways. Most of land uses in urbanized areas are point source pollution. Included here are, as shown in Table 3, residential land use, Industrial activities and livestock production activities. Frequently, however, land use in urban land use can also contribute to water pollutions as non-point sources. Impervious surfaces such as roads, driveways, rooftops and the like lead to increased storm water runoff to stream. Also, increased vehicle travel and industry activity lead to greater airborne emissions that eventually settle in the lake or reservoir and its tributaries. Emissions from either septic systems or municipal wastewater treatment plants are higher when land is in an urbanized use. 
Secondary, land use impacts on water quality of agricultural activities vary depending on various factors. Whether pollution increases or decreases depends on the type of agriculture conducted on the land such as row crops, pasture land, feedlots, and so forth; what management practice the farmers employs and the level of chemical use on the land. In general, agricultural activities can lead to an increased influx of nitrogen into water as a result of many factors, including fertilizer application, manure of livestock production, sludge from municipal sewage treatment plants, and aeration of the soil. The precise role of agriculture in the contamination of ground and surface water is difficult to quantity. In the case of Paldang, monitoring is not sufficient to establish the extent of nutrient pollution from agricultural land use and thus it is difficult to distinguish between agricultural pollution and pollution by untreated sewage.

More serious impacts on water quality from agricultural land use in the watershed of Paldang may be caused by the application of pesticides. Generally, the application of pesticides for agricultural production poses a danger to surface and groundwater resources, since pesticide compounds are designed to be toxic and persistent. Pesticide metabolites might be as toxic and as mobile as the parent compound. In human and animal, pesticides can have both acute and chronic toxic effects. These compounds can accumulate in fatty tissues (bio-concentration) and in the food chain (bio-magnification) (FAO, 1996).

Thirdly, forests land use is generally considered beneficial to the water quality. Forests capture rainfall and reduce runoff, filter nutrient and sediment, and stabilizing soils. Forests are also checkers of soil erosion. In Paldang watershed, due to steep slope of the area, forest land use can contribute significantly to the water quality protection. Protection is largely 
because of under-story vegetation and the stabilizing effects of the root network. On steep slopes, the net stabilizing effect of trees is usually positive. Vegetation cover can prevent the occurrence of shallow landslides. Large landslides on steep terrain can also be influenced appreciably by vegetation cover. These large landslides may contribute the bulk of the sediment.

Fourthly, the land uses for the livestock production may contributes to degradation of water quality in several ways. To begin with, these land uses may affect the bacteriological quality of water, which can create health concerns for downstream water users. Particularly, the concentration of pathogenic bacteria in surface waters may increase as a consequence of riparian grazing activities of waste influx from livestock production in the Paldang watershed. In addition, these land uses may result in the contamination of irrigation water for agricultural purpose, the eutrophication of lake and reservoir as well as degradation of living environment due to mal-odor and insects.

Land use for livestock production may also contribute to an increased concentration of heavy metals in water resources. A direct pathway is the application of livestock manure and sludge from sewage treatment plants, which may contain high concentrations of heavy metals. For example, pig manure often contains high concentrations of copper (FAO, 1996). Indirectly, these land use activities may affect heavy metal concentration in surface and groundwater by increasing the mobility of metals in the soil. Heavy metals in the soil may be transferred into water by erosive processes. The acidification of soil, caused by ammonia volatilization from manure application or in animal feedlots, may increase the solubility of heavy metals stored in the soil, and thus the influx into surface and groundwater (Kiersch, 
2000).

\section{AN OPTIMAL GOVERNANCE MODEL OF LAND USE IN WATERSHED}

Thus far, the discussion has focused on the delineation of governance mechanisms and the classification of land use activities in terms of impacts on water quality. This section construct an optimal governance model of land use in watershed by aligning these land use activities with governance mechanisms in such a way that the predetermined criteria could be met.

\section{Governing Principles and Alignment Method}

In designing an optimal governance model it is necessary to select some principles based on which the optimality of the alignment can be evaluated. Following the literatures on policy sciences, this study focuses on the two governing principles: efficiency and equity.4 As for efficiency, traditional approaches to land use governance have favored Pareto efficiency. But this criterion can only be justified in a world where transaction costs are zero and institutional arrangements play no role. We may need to have other efficiency criteria which should be applicable to situations where transaction costs are prevalent and institutions matter. Based on these requirements, the minimization of governance costs has been selected as the efficiency

4) Some people regard efficiency as the only governing principle warranting a policy intervention, while others favor principles such as justice and liberty. The literature on law, economics and the policy sciences is replete with various conceptual definitions of what is known as governing principles. These can also be described as goals, justifications, 
criterion.5 The governance costs in this study consist of the three types of costs such as nuisance costs, prevention costs and administrative costs. 6 These costs occur singly or in combination when government attempts to control land use activities.

Another governing principle is the concept of equity. As the government, being the main governance body, has the authority to legitimately use coercive power, the equity principle is especially relevant to the designing of optimal land use governance model. Moreover, the equity principle can be seen as being complementary to the efficiency criterion used in this paper. For the purposes of this paper, equity can be defined as a condition under which governance mechanism are expected to make equitable decisions; that is, to treat people with similar problems in a similar manner (Bryson \& Ring, P.S., 1990). The concern for equity also requires that governance structures ensure equitable exchanges, the fair treatment of decision makers, and the equitable distribution of costs and benefits resulting from land use decisions.

Having identified the governing principles, it is now necessary to combine these elements to develop a governance model. To this end, this study expectations, criteria for evaluation, or values.

5) This efficiency criterion is often called Kaldor-Hicks efficiency. According to this efficiency criterion, a governance mechanism can be regarded as being efficient if the benefits from using new governance mechanism are greater than the sum of the costs of using old one and compensation costs for the losers. This efficiency criterion is capable of overcoming many of the problems associated with Pareto efficiency.

6) The nuisance costs comprise both the direct costs resulting from the harmful externalities and the indirect costs such as the diminution of the property value due to the externalities. The prevention costs includes non-administrative expenditures made, or opportunity costs incurred, by either a nuisance maker or his injured neighbor to reduce the level of nuisance costs. The administrative costs will be used to encompass both public and private costs of getting information, negotiating, writing agreements and laws, policing agreements and rules, and arranging for the execution of preventive measures (Ellickson, 1973). 
utilizes the method suggested in transaction costs economics by Williamson (1996). The basic premise of this method is that land use decisions, which differ in their attributes, be aligned with governance mechanisms, which differ in their costs and competencies, in a discriminating manner. In other words, the appropriate governance mechanism, the one minimizing governance costs, should be selected for each type of land use activities.

Conceptually, while this method appears to be straightforward, there is a serious pitfall that needs to be addressed during its implementation. More specifically, there is a possibility of facing a measurement problem during the estimation of governance costs. Although various empirical studies have been undertaken, some definitional ambiguities still exist regarding the concept of governance costs. Furthermore no universally accepted method to measure governance costs exists, and the results of such measurements are not always completely satisfying (Furubotn \& Richter, 1991).

Recently, Williamson has developed an analytical method to overcome these measurement problems involved in the estimation of transaction costs. This method introduces a so-called the discrete structural analysis that can be used to make comparisons of the magnitude of transaction costs (Williamson, 1996).7 The discrete structural analysis can be carried out without any elaborate mathematical apparatus or marginal calculation. With this methodology, it may be sufficient to use much cruder and simpler arguments to demonstrate the differences in the magnitude of governance costs.

7) Herbert Simon was the first to introduce the term "discrete structural analysis" in his study on comparative economic organization. He observing that "As economics expands beyond its central core of price theory, and its central concern with quantities of commodities and money, we observe in it.... a shift from a highly quantitative analysis, in which equilibration at the margin plays a central role, to a much more qualitative 


\section{An Optimal Land Use Governance Model}

This section develops the optimal governance model of land use in the watershed of Paldang reservoir. The model is composed of several governing mechanisms aligned exclusively to various types of land use activities. In order for the model to be manageable, we identify two representative cases for each land use type. These cases comprise both the land use activities with typical impacts and those with potentially serious impacts. 8 A detail description of the governance mechanism for these activities will be carried out in the following. Table 4 details the structure of the land use governance model.

\section{1) Urban Land Uses}

The typical urban land use activities tend to produce the impacts with minor, pervasive, un-measurable and third party effects. The real examples of these activities are most of point source pollution and a part of non-point pollution caused by household wastewater as well as run-off from impervious surface of urban areas. For these activities, it is appropriate to apply the governance mechanism L-1. But this governance mechanism based on liability rules can only be the second best solution. In fact, the governance mechanisms involving property or liability rules cannot readily

institutional analysis, in which discrete structural alternatives are compared."(Simon, 1978). 8 The seriousness of the impacts each land use activities can produce would be determined by such factors as the location and nature of activities and the physical characteristics of the target area including slope, soil content and rainfall pattern. 
be employed in such situation. Nor can a structure based on inalienability rule. The governance structure based on liability rule is selected because it will generate less governance costs than alternative mechanisms. Some of the specific policy measures adopted are the levy of user charges and the imposition of effluent taxes on urban land use activities.

There are some urban land use activities that produce persistent, irreversible and potentially serious negative impacts on water quality as in the case of traditional industrial sites. It would be appropriate to select governance structure similar to I-1 involving conventional inalienability rules. Under this rule, the possibility of making further land use decisions is simply precluded. Real world examples of such a situation include the industrial activities producing toxic waste with potentially serious harms. Since it is quite likely that the impact of our present decisions extends to generations yet unborn, the conventional inalienability rules become most relevant. This type of governance structure, however, may result in equity issues. It is likely that landowners, who otherwise had put the land to its most profitable use, must bear the costs. Thus, the governance structure $\mathrm{L}-2$ is suggested as a viable alternative. Under this structure, government may purchase the entitlements given to the individual owners to develop the affected areas.

2) Agricultural Land Use

In terms of impacts on water quality, we can differentiate two types of agricultural land use activities. One type of these activities may produce non-point source pollutions and require the application of ordinary fertilizer. The external impacts caused by this type of land use activities are 
considered to be minor, intermittent, broad and un-measurable. In such a situation, the governance structure $\mathrm{L}^{-1}$ can be chosen. The governance mechanism involving liability rules would be as a second-best solution as in the case of urban land use activities. This mechanism will generate less governance costs than alternative structures. Some of the specific policy measures adopted are the levy of user charges and the imposition of effluent taxes on input used for agricultural activities. The governance mechanism, however, may bring about serious equity issues. It is likely that farmers, whose economic status can be relatively in needy circumstance, must bear the entire costs. In this case, we may provide subsidies for those whose burdens appear to be potentially serious. The subsidy in the case should focus on income side and should not distort the price of input for the agricultural production.

Unlike the first type, the second type of agricultural land use activities may produce irreversible and potentially serious effects on the quality of water in reservoir. Included here are the agricultural activities which occur in areas adjacent to lake or river and require to apply a large amount of pesticide. This situation requires to adopt the governance mechanism I-2. This governance structure has been developed based on inalienability with limited use. Under this structure, the government may put some restriction on land use activities, thereby preventing landowners from using their land adjacent to river or lake for certain purposes. A typical example of such case would be land use zoning law. Since it is extremely difficult to define the owner responsible for pollution and to adequately measure the damage, any governance structure founded upon either property or liability rules would appear to be inappropriate.

There are agricultural land use activities that can bring about positive 
impacts on water quality. The so-called environmentally sustainable agriculture is the case in point. This agriculture practice requires not only to adopt special cultivation method, but also to apply the fertilizer with little impacts. It is likely, however, the farmers do not practice this agricultural activities up to socially optimal level, because a large part of the benefits generated by these activities are external to the farmers. This situation requires the application of the governance mechanism $\mathrm{P}-1$ that involves the property rules with the provision of subsidy. Under this mechanism, the farmers are required to practice the agricultural activities to a predetermined level. As far as he or she obtain sufficient level, he or she would be provided with subsidy enough to cover the opportunity cost.

\section{3) Forest Land Use}

As discussed previously, since we assumed that most of forest land use produce positive impacts on water quality, the governance mechanisms applicable to these activities may be different from the cases examined thus far. We may differentiate two situations in which the benefits produced by the land use activities may be different. If benefits from the activities are deemed to be minor and their impacts are spatially limited, we may adopt the governance mechanism $\mathrm{P}-1$. This is the governance mechanism, which can not only facilitates the forest land use activities through market incentives, but also minimize the governance costs. Under this mechanism, we can expect individual decision makers to respond to the incentives created by the government's tax or subsidy schemes. If equity issues arise in the provision of such land use activities, then it is more appropriate to use subsidies rather than other alternatives such as mandatory standards. 
If the benefits generated by forest land use are critical for water quality and their impacts are spatially extensive, we may adopt the governance structure either I-2 or L-2. For example, areas adjacent to river or lake, which are considered critical for water quality protection, are the case in point. In such cases, the insufficient provision of such land use activities inflicts substantial harm on water quality and influences a large number of parties. Thus, the government tends to employ a governance mechanism that stipulates that the provision of a sufficient amount of such land use activities is mandatory. Alternatively, government may resort to the power of eminent domain to acquire sites necessary for the provision of these activities. As such, this governance structure is founded on liability rules with proper compensation.

\section{4) Livestock Farm Land Use}

The governance mechanism controlling land use for the livestock production can be differentiated depending upon the seriousness of impacts on water quality. When the impacts on water quality of these livestock farm land use are not serious and persistent, then the governance structure I-2 may be utilized. This mechanism requires a small set of actions while still permitting a wide range of other uses. These required actions may imply either the payment of charges or the mandated actions through which the government may attain its objectives. As it tends to incur less governance costs, it is generally preferable to use the payment of charge method.

Applying a governance structure based on inalienability rules with required uses, however, may lead to distributive side effects. As the restrictions imposed by this mechanism may single out a particular type of 
land use decision for special treatment, such restrictions usually cannot be justified on re-distributive grounds. For example, those who own the land at the time the regulation is passed, bear the costs along with those who would have benefited if the property had been put to its most profitable use. The government's purchase of development rights is a non-coercive alternative to this governance structure that forces the government to take into account the costs of restricting land use.

There are cases where the land use impacts of livestock production on water quality is potentially serious and persistent. For example are land use activities for livestock production locating adjacent to the lake and river. In this case, we opt for the governance structure I- 1 as in the case of industrial activities. Under this rule, the possibility of making further land use decisions is simply precluded. Real world examples of such a situation can be designation of special districts where most of land use activities are strictly prohibited except for such activities producing positive impacts. If this governance mechanism results in equity issues, the governance mechanism L-2 is recommended as a viable alternative as discussed in urban land use case. Under this mechanism, government may purchase the entitlements given to the individual owners to develop the affected areas.

\section{CONCLUSION}

Thus far, optimal governance models of land use from property rights perspective have been developed with special reference to Paldang reservoir in Korea. The key idea underpinning this governance model is that 
land use decisions, which differ in their attributes, can properly be aligned with governance mechanism. Given the intrinsic limitations of the measurement of governance costs, this research has used the discrete structural alternative analysis in the alignment of the land use decisions and governance mechanism. A model developed in such a manner appears to prescribe very diverse and specific governance structures, and as such, the relevance of this model to the real world situation is much greater.

A brief discussion of the comparison of this model with the conventional land use governance model based on the market failure analysis will highlight the usefulness of the model introduced in this paper. To begin with, unlike the conventional model, the model presented in this paper prescribes different governance mechanism for different types of land use activities, thereby strengthening the practical value of the model. As previously observed, this model's practical relevance has been enhanced through the introduction of greater reality and complexity in the classification of both land use decisions and governance mechanism. Once these two dimensions are given greater resolution, a more appropriate policy prescription for each type of land use activities might result.

Second, while the conventional land use governance model is primarily concerned with the efficiency criteria, viewing the policy's redistributive impact as an unwelcome side effect, this land use governance model has been developed with explicit attention being paid to both the efficiency and the equity aspects of land use governance. Thus, this model can easily achieve some specialized distributive goals by applying the proper governance structures. From these discussions, we may conclude that the land use governance model proposed herein appears more suitable than the conventional approach, as it is has been developed with a more accurate 
understanding of the complex nature of land use activities and governance mechanisms.

Finally, even if the land use governance model proposed in this paper has merit, additional work will be necessary to make it even more useful. First, valid and reliable instruments to classify the dimensions of land use decisions need to be developed. Second, there is a need to further develop the more diversified governance mechanisms. Third, more empirical studies need to be done on the comparative strengths and weaknesses of the different governance mechanisms used in controlling various land use activities, and on the different governing principles. Through these improvements the model proposed here will have a greater practical relevance and be freed from the conceptual deficiencies. 


\section{REFERENCES}

Alchian, A. A. and Demsets, H. (1973) "The Property Rights Paradigm," Journal of Economic History $33: 16-27$.

Barzel, Yoram (1989) Economic Analysis of Property Rights, New York: Cambridge University Press.

Bromley, D. W. (1991) Environment and Economy: Property Rights and Public Policy, Cambridge, MA: Blackwell Publishers.

Bryson, J.M. and Ring, P.S. (1990) "A Transaction-based Approach to Policy Intervention," Policy Sciences 23: 205-229.

Calabresi, G. and A. D. Melamed (1972) "Property Rules, Liability Rules, and Inalienability: One View of the Cathedral," 85 Harvard Law Review, 1089.

Choi, J. Y. et al. (1998) Management Strategy of Non-point Source Pollution in Agricultural Areas, The Korea Research Institute for Environmental Policy and Evaluation, Seoul, Korea.

Coase, R. (1960) "The Problem of Social Cost," Journal of Law and Economics 3, pp.1-44.

Coase, R. (1991) "The Institutional Structure of Production," In Coase, R. H. (ed.) Essays on Economic and Economists, Chicago, IL: University of Chicago Press.

De Alessi (1980) "The Economics of Property Rights: A Review of the Evidence," Research in Law and Economics 2 : 1-47.

Demsetz, H. (1967) "Towards a Theory of Property Rights," A.E.R Papers and Proceedings $57: 347-59$. 
Eggertsson, T. (1990) Economic Behavior and Institutions. New York: Cambridge University Press.

Ellickson, R. C. (1973) "Alternative to Zoning: Covenants, Nuisance Rules and Fines as Land Use Control," University of Chicago Law Review 40(3): 681-714.

Ellickson R. C. (1977) "Suburban Growth Controls: An Economic and Legal Analysis," Yale Law Journal 86 : 385-511.

FAO (1996) Steps towards a participatory and integrated approach to watershed management. Report of the inter-regional Project for Paticipatory Upland Conservation and Development.

Fischel, W. A. (1987) "The Economics of Land Use Exactions: A Property Rights Analysis," Law and Contemporary Problems $50:$ 101-113.

Furubotn, E. G. \& Richter, R. (1991), "The New Institutional Economics: An Assessment," in Furubotn, E. G. \& R. Richter (eds.), The New Institutional Economics. College Station, TX: Texas A \& M Univ. Press.

Hardin, G. (1968) "The Tragedy of Commons," Science $162: 1243-248$.

Kaplow, L. \& Shavell, S. (1996), "Property Rules versus Liability Rules: An Economic Analysis," Harvard Law Review, 109 : 713-90.

Kiersch, B. (2000) Land Use Impacts on Water Resources : a Literature review, Land and Water Development Division, FAO, Rome.

Krauss, M. I. (1999) "Property Rules vs Liability Rules," in Bouckaert, B. and De Geest, G. (eds.) Encyclopedia of Law and Economics, Cheltenham: Edward Elgar.

Libecap, G. D. (1989), Contracting for Property Rights. New York: Cambridge University Press.

Medema S. G. and Zerbe, Jr. (1999) "The Coase Theorem," in Encyclopedia of Law and Economics, Bouckaert, B. and De Geest, G. (eds.), 
Cheltenham: Edward Elgar.

Mercuro, N. and Medema, S.G (1997) Economics and the Law: from Posner to Post Modernism, Princeton, NJ: Princeton University Press.

Ministry of Environment (2000) Management Strategy of Non-point Source Pollution in the Paldang Reservoir, Seoul, Korea.

Ministry of Environment (2003) Environmental Statistics for the Special District of Water Quality Management, Seoul, Korea.

North, D. C. (1990). Institutions, Institutional Change, and Economic History. New York: Cambridge Univ. Press.

Ostrom, E. (1990) Governing the Commons. New York: Cambridge University Press.

Polinsky, M. A. (1980), "On the Choice Between Property Rule and Liability Rule," Economic Inquiry, 18: 233-46.

Posner, R. (1992) Economic Analysis of Law, 4th ed., Boston: Little, Brown and Co.

Rose-Ackerman, S. (1985) "Inalienability and the Theory of Property Rights," Columbia Law Review 85 : 931-969.

Shin, H. S. et al. (1990) "Management Alternatives of Livestock Wastes for Water Resource Conservation," The Korean Journal of Solid Wastes Treatment 7(1): 45-52.

Simon, H. (1978) "Rationality as Process and as Production of Thought," American Economic Review 68 (May) : 1-16.

Williamson, O. E. (1996) The Mechanisms of Governance, New York: Oxford University Press. 
Table1. Types of Governance Mechanisms

\begin{tabular}{|c|l|l|}
\hline Type & \multicolumn{1}{|c|}{ Distribution of Property rights } & \multicolumn{1}{|c|}{ Rules of protection of property rights } \\
\hline P-1 & Individual(responder) & Property rules \\
\hline P-2 & Individual(decision maker) & Property rules \\
\hline L-1 & Individual(responder) & Liability rules \\
\hline L-2 & Individual(decision maker) & Liability rules \\
\hline I-1 & Government & Inanlienability rules \\
\hline I-2 & Government and Individual & Inanlienability rules with required use \\
\hline I-3 & Government and Individual & Inanlienability rules with limitied use \\
\hline I-4 & Government & Inanlienability rules with coerced use \\
\hline
\end{tabular}

Table 2. Land Use in the Watershed of Paldang Reservoir by Sub-regions

(Unit: ton/year, \%)

\begin{tabular}{|c|r|r|r|r|r|r|r|r|}
\hline & Total & Water & Urban & $\begin{array}{r}\text { Vacant } \\
\text { lot }\end{array}$ & Agriculture & Forest & Pasture & Wetland \\
\hline Total & $\begin{array}{r}20,459.5 \\
(100.0)\end{array}$ & $\begin{array}{r}249.3 \\
(1.2)\end{array}$ & $\begin{array}{r}168.9 \\
(0.8)\end{array}$ & $\begin{array}{r}227.9 \\
(1.1)\end{array}$ & $\begin{array}{r}2535.9 \\
(12.4)\end{array}$ & $\begin{array}{r}16,739.6 \\
(81.8)\end{array}$ & $\begin{array}{r}537.9 \\
(2.6)\end{array}$ & $\begin{array}{r}0.4 \\
(0.0)\end{array}$ \\
\hline $\begin{array}{c}\text { Southern } \\
\text { Han river }\end{array}$ & $\begin{array}{r}12,328.4 \\
(100.0)\end{array}$ & $\begin{array}{r}116.7 \\
(0.9)\end{array}$ & $\begin{array}{r}111.7 \\
(0.9)\end{array}$ & $\begin{array}{r}175.1 \\
(1.4)\end{array}$ & $\begin{array}{r}1914 \\
(15.5)\end{array}$ & $\begin{array}{r}9754.6 \\
(79.1)\end{array}$ & $\begin{array}{r}394.6 \\
(3.2)\end{array}$ & $\begin{array}{r}0.3 \\
(0.0)\end{array}$ \\
\hline $\begin{array}{c}\text { Northern } \\
\text { Han river }\end{array}$ & $\begin{array}{r}7,469.0 \\
(100.0)\end{array}$ & $\begin{array}{r}129.4 \\
(1.7)\end{array}$ & $\begin{array}{r}36.0 \\
(0.5)\end{array}$ & $\begin{array}{r}44.7 \\
(0.6)\end{array}$ & $\begin{array}{r}493.2 \\
(6.6)\end{array}$ & $\begin{array}{r}6546.0 \\
(87.6)\end{array}$ & $\begin{array}{r}117 \\
(1.6)\end{array}$ & $\begin{array}{r}0.1 \\
(0.0)\end{array}$ \\
\hline $\begin{array}{c}\text { Kyungan } \\
\text { river }\end{array}$ & $\begin{array}{r}559.4 \\
(100.0)\end{array}$ & $\begin{array}{r}2.0 \\
(0.4)\end{array}$ & $\begin{array}{r}20.1 \\
(3.6)\end{array}$ & $\begin{array}{r}7.4 \\
(1.3)\end{array}$ & $\begin{array}{r}119.5 \\
(21.4)\end{array}$ & $\begin{array}{r}371.0 \\
(66.3)\end{array}$ & $\begin{array}{r}24.4 \\
(4.4)\end{array}$ & $\begin{array}{r}0.0 \\
(0.0)\end{array}$ \\
\hline
\end{tabular}




\begin{tabular}{|c|r|r|r|r|r|r|r|r|}
\hline Paldang & 101.7 & 12.3 & 0.5 & 0.3 & 10.8 & 57.5 & 2.0 & 0.0 \\
Reservoir & $(100.0)$ & $(12.1)$ & $(0.4)$ & $(0.2)$ & $(10.6)$ & $(56.5)$ & $(2 . .0)$ & $(0.0)$ \\
\hline
\end{tabular}



Figure 1. The Map of the Paldang Reservoir Watershed 
Table 3. The Contribution of Each Pollution Source by Pollution Types

(Unit: ton/year, \%)

\begin{tabular}{|c|c|c|c|c|c|c|}
\hline & \multicolumn{2}{|c|}{ Nutrient } & \multicolumn{2}{|c|}{ Nitrogen Load } & \multicolumn{2}{|c|}{ Phosphorous } \\
\hline Point Source & 41,442 & 55.5 & 14,190 & 55.7 & 1,933 & 79.1 \\
\hline Household & 22,177 & 29.7 & 8,023 & 31.4 & 701 & 28.7 \\
\hline Industrial & 5,898 & 7.9 & 1,642 & 6.4 & 501 & 20.5 \\
\hline Livestock & 13,366 & 17.9 & 4,525 & 17.7 & 731 & 29.9 \\
\hline Non-point Source & 33,194 & 44.4 & 11,300 & 44.3 & 511 & 20.9 \\
\hline Total & 74,636 & 100.0 & 25,490 & 100.0 & 2,444 & 100.0 \\
\hline
\end{tabular}


Table 4. Governance Mechanisms for Each Type of Land Use Activities

\begin{tabular}{|c|c|c|c|c|}
\hline $\begin{array}{l}\text { Land use } \\
\text { type }\end{array}$ & \multicolumn{2}{|c|}{ Nature and Types of Land Use Impacts } & $\begin{array}{l}\text { Governance } \\
\text { Mechanisms }\end{array}$ & Policy measures \\
\hline \multirow{2}{*}{$\begin{array}{l}\text { Urban Land } \\
\text { Use }\end{array}$} & $\begin{array}{l}\text { Typical and Minor } \\
\text { harms }\end{array}$ & $\begin{array}{l}\text { Point source pollution, surface water } \\
\text { run-off }\end{array}$ & L-1 & $\begin{array}{l}\text { Levy of user charge, Imposition of } \\
\text { effluent tax }\end{array}$ \\
\hline & $\begin{array}{l}\text { Potentially serious } \\
\text { harms }\end{array}$ & Discharge of toxic industrial waste & I-1, L-2 & Moratorium, Government expropriation \\
\hline \multirow{3}{*}{$\begin{array}{l}\text { Agricultural } \\
\text { Land Use }\end{array}$} & $\begin{array}{l}\text { Typical and minor } \\
\text { harms }\end{array}$ & $\begin{array}{l}\text { Non-point source pollution,, Application } \\
\text { of fertilizer, }\end{array}$ & $L-1$ & $\begin{array}{l}\text { Levy of charge, Imposition of tax on } \\
\text { input for agricultural production }\end{array}$ \\
\hline & $\begin{array}{l}\text { Potentially serious } \\
\text { harms }\end{array}$ & $\begin{array}{l}\text { Application of pesticides, Location } \\
\text { adjacent to water resource }\end{array}$ & $1-2$ & Mandatory standards \\
\hline & Substantial benefits & $\begin{array}{l}\text { Reduction of fertilizer use, Practice of } \\
\text { environmentally sustainable agricultural }\end{array}$ & $P-1$ & $\begin{array}{l}\text { Redefinition of property rights, provision } \\
\text { of subsidy }\end{array}$ \\
\hline \multirow{2}{*}{$\begin{array}{c}\text { Forest Land } \\
\text { Use }\end{array}$} & $\begin{array}{l}\text { Typical and minor } \\
\text { benefits }\end{array}$ & $\begin{array}{l}\text { Reduction of run-off, filtration of nutrient } \\
\text { and sediment, check of soil erosion }\end{array}$ & $P-1$ & $\begin{array}{l}\text { Redefinition of property rights, provision } \\
\text { of subsidy }\end{array}$ \\
\hline & $\begin{array}{l}\text { Potentially substantial } \\
\text { benefits }\end{array}$ & Prevention of large landslide & I-2, L-2 & $\begin{array}{l}\text { Mandatory standard, Purchase of } \\
\text { development rights }\end{array}$ \\
\hline \multirow{2}{*}{$\begin{array}{l}\text { Livestock } \\
\text { Farm Land } \\
\text { Use }\end{array}$} & $\begin{array}{l}\text { Typical and minor } \\
\text { harms }\end{array}$ & $\begin{array}{l}\text { Point source pollution, increase of } \\
\text { bacteriological level }\end{array}$ & I-2. & Mandatory standards \\
\hline & $\begin{array}{l}\text { Potentially serious } \\
\text { harms }\end{array}$ & $\begin{array}{l}\text { Concentration of heavy metal, influx of } \\
\text { pathogens }\end{array}$ & $\mathrm{I}-1, \mathrm{~L}-2$ & Moratorium, Government expropriation \\
\hline
\end{tabular}

